\title{
PERANCANGAN ANIMASI INTERAKTIF PENGENALAN PETA INDONESIA SEBAGAI MEDIA PEMBELAJARAN UNTUK ANAK SEKOLAH DASAR
}

\author{
Ibnu Dwi Lesmono ${ }^{1}$, Mulyadi ${ }^{2}$ \\ ${ }^{1,2}$ Program Studi Sistem Informasi, ${ }^{1,2}$ Universitas Bina Sarana Informatika, \\ E-mail: ${ }^{1}$ ibnu.idl@bsi.ac.id, ${ }^{2}$ mulyadi.myd@bsi.ac.id
}

\begin{abstract}
Development of information and communication technology in this period have a very large role, especially in the field of education. With the influence of technology, learning becomes easier system to be delivered. Therefore, when presenting the information as a medium of information supported with advanced multimedia technology and attractively packed information submitted is expected to be channeled properly and accurately to the recipient. Media Animation is a great solution to simplify the process of delivering information. With animation produces media images, text, audio (voice), animations and videos that interact with each other. Stages in the process of this research is the analysis phase, design, implementation, and testing. The research objective of this report is to facilitate the students of primary school in studying the culture and islands in Indonesia
\end{abstract}

Keywords: information technology, animation, Multimedia, waterfall, Province

Abstrak -Perkembangan teknologi informasi dan teknologi komunikasi dalam periode ini memiliki peran yang sangat besar, terutama di bidang pendidikan. Dengan pengaruh teknologi, sistem belajar menjadi lebih mudah untuk disampaikan. Oleh karena itu, saat menyampaikan informasi sebagai media informasi didukung dengan teknologi multimedia canggih dan informasi menarik dikemas disampaikan diharapkan akan disalurkan dengan benar dan akurant kepada penerima. Media Animasi adalah solusi yang bagus untuk menyederhanakan proses penyampaian informasi. Dengan animasi yang menghasilkan media gambar, teks, audio (suara), animasi dan video yang berinteraksi satu sama lain. Metode penelitian yang di gunakan adalah metode waterfall dengan Tahapan dalam proses penelitian ini adalah tahap analisis, desain, implementasi, dan pengujian. Sedangkan Tujuan dari penelitian ini adalah untuk merancang suatu aplikasi multimedia yang dapat membantu guru serta menunjang dalam penyampaian materi pengetahuan mengenai provinsi-provinsi di Indonesia pada tingkat sekolah dasar.

Kata Kunci: informasi, MultiMedia, Animasi, Waterfall, provinsi.

\section{A.PENDAHULUAN}

Pendidikan sekolah dasar memiliki pengaruh dalam membangun kecerdasan siswa di dunia pendidikan Indonesia, karena ditingkat pendidikan ini, dasar-dasar dari ilmu pengetahuan diberikan.

Kemampuan siswa dalam menangkap ilmu yang diberikan disekolah dipengaruhi pula dengan media pembelajaran yang diberikan. Bila media pembelajaran bersifat manual diberikan secara terus menerus atau guru menjelaskan secara teori dari sumber referensi yang ada, maka penyerapan ilmu siswa pun dirasa membosankan, terlebih ditingkat sekolah dasar(Virvou, 2005).

Salah satu ilmu yang dipelajari oleh siswa sekolah dasar adalah pengetahuan mengenai informasi seputar provinsi-provinsi yang ada di negara Indonesia, baik letak geografis maupun seni dan kebudayaannya. Penyampaian ilmu yang diberikan untuk kasus ini, tentu saja tidak bisa hanya sebatas penyampaian secara lisan saja oleh guru, tetapi dibutuhkan media pendukung sebagai sarana penyampaian ilmu(Adiwisastra, 2015).

SDN Cipondoh 4 Tangerang dijadikan objek dalam penelitian ini. Kemampuan siswa-siswi mengenai provinsi-provinsi di Indonesia dijadikan fokus dalam perancangan aplikasi multimedia dalam penelitian ini. Perancangan aplikasi ini akan membantu siswa dalam meningkatkan pengetahuan mengenai provinsiprovinsi beserta seni kebudayaannya yang ada di Indonesia.

Peran guru dalam menyampaikan materi pembelajaran pun dapat terbantu karena secara visual aplikasi dibuat menarik sesuai dengan tingkatan usia siswa sekolah dasar. 
Selain mendapat ilmu dari guru dikelas, siswa dapat memanfaatkan aplikasi multimedia yang dirancang untuk meningkatkan kemampuan dalam wawasan provinsi-provinsi yang ada di Indonesia.masalah penelitian dalam penelitian ini adalah peran guru di sekolah dasar dalam penyampaian materi pembelajaran masih bersifat teoritis, khususnya mengenai informasi seputar provinsi-provinsi yang ada di Indonesia. Penelitian ini penting dilakukan karena setelah peneliti melakukan observasi ke sejumlah sekolah dasar ternyata belum di temui di sekolah dasar guru menggunakan multimedia dengan animasi dalam menyampaikan penyampaian materi pengetahuan tentang peta indonesia khussnya mengenai provinsi-provinsi di Indonesia pada tingkat sekolah dasar.

\section{B. TINJAUAN PUSTAKA}

Aplikasi adalah kumpulan perintah program yang dibuat untuk melakukan pekerjaan-pekerjaan tertentu (Hendrayudi, 2009). Sedangkan multimedia adalah media yang menggabungkan dua unsur atau lebih media yang terdiri dari teks, grafis, gambar, foto, audio, video dan animasi secara terintegrasi (Nazir, 2011).

Aplikasi multimedia sering dimanfaatkan juga dalam dunia pendidikan dan bisnis. Didunia pendidikan, multimedia digunakan sebagai sarana pengajaran, baik dalam kelas maupun secara individual(Hardiyan, 2017).Ada pula pengertian lain dari multimedia, yaitu, merupakan kombinasi teks, seni, suara, gambar, animasi, dan video yang disampaikan atau dikontrol secara interaktif (Binanto, 2010). Berdasarkan pengertian ini, maka multimedia dapat dibedakan menjadi tiga jenis, diantaranya adalah:

1. Multimedia Interaktif

Pengguna dapat mengontrol apa dan kapan elemen-elemen multimedia akan ditampilkan. Contoh: world wide web, mobile banking, game online, website.

\section{Multimedia Hiperaktif}

Multimedia jenis ini mempunyai suatu struktur dari elemen-elemen terkait dengan pengguna yang dapat mengarahkannya. Dapat dikatakan bahwa multimedia jenis ini mempunyai banyak tautan (link) yang menghubungkan elemenelemen multimedia yang ada. Contoh: game, CD interaktif, aplikasi program, virtual reality.

\section{Multimedia Linier}

Pengguna hanya menjadi penonton dan menikmati produk multimedia yang disajikan dari awal hingga akhir. Contoh: film, musik, ebook, TV.

\section{Animasi}

Animasi pada dasarnya merupakan kumpulan image sekuensial (berurutan) yang menyatakan pergerakan, dimana image tersebut ditampilkan secara berurutan dalam waktu yang relatif cepat(Lesmono, 2019).

Saat ini animasi tidak hanya digunakan untuk media hiburan saja, tetapi animasi banyak digunakan sebagai media penunjang bagi pembelajaran didunia pendidikan, baik pendidikan formal maupun nonformal.Animasi merupakan kumpulan gambar yang diolah sedemikian rupa sehingga menghasilkan gerakan, perubahan visual sepanjang waktu yang memberikan kekuatan besar pada proyek multimedia(Suheri, 2006). Saat ini banyak aplikasi multimedia yang mengediakan fasilitas animasi.

Dahulu animasi mempunyai prinsip sederhana, namun sekarang telah berkembang menjadi beberapa jenis. Berikut beberapa jenis animasi (Pranowo, 2010):

\section{Animasi 2D (Dua Dimensi)}

Animasi ini yang paling akrab dengan keseharian kita. Biasa disebut juga dengan film kartun. Kartun sendiri berasal dari kata Cartoon, yang berarti gambar lucu. Memang film kartun ini kebanyakan film yang lucu. Contoh dari film 2D adalah Shincan, Looney Tunes, Pink Panther, Tom and Jerry, dan Scooby Doo.

\section{Animasi 3D (Tiga Dimensi)}

Perkembangan teknologi dan dunia komputer membuat teknik pembuatan animasi 3D semakin berkembang dan maju pesat. Animasi $3 \mathrm{D}$ adalah perkembangan dari animasi 2D. Dengan animasi 3D, karakter yang diperlihatkan semakin hidup dan nyata, mendektati wujud asli. Contoh film dengan menggunakan animasi 3D adalah Bugs Life, Antz, Toy Story, Monster Inc, Final Fantasy, hingga Finding Nemo.

\section{Animasi Tanah Liat (Clay Animation)}

Meski namanya Clay (tanah liat), namun yang dipakai bukanlah tanah liat biasa. Animasi ini menggunakan plasticin, bahan lentur seperti permen karet yang ditemukan pada tahun 1897. Tokoh-tokoh pada animasi clay dibuat 
dengan menggunakan rangka khusus untuk kerangka tubuhnya, baru kemudian dilapisi dengan plasticin. Contoh penerapan pada film animasi ini adalah Chicken Run dari Dream Work Pictures.

\section{Editor Multimedia Flash}

Dalam perancangan aplikasi penelitian ini, peneliti menggunakan salah satu editor multimedia flash yang mudah digunakan, yaitu adobe flash yang merupakan salah satu produk perangkat lunak komputer unggulan yang dikeluarkan oleh Adobe Systems sebagai editor multimedia flash untuk membuat gambar vektor maupun animasi gambar (Saeba, 2008)

Sedangkan untuk versi yang digunakan dalam perancangan aplikasi penelitian ini, menggunakan Adobe Flash Professional CS6 yang merupakan sebuah software yang didesain khusus oleh Adobe dan program aplikasi standar authoring tool professional dan biasa juga digunakan untuk membuat animasi dan bitmap yang sangat menarik (Kurniawan, 2015). Adobe Flash CS6 menyediakan berbagai macam fitur yang akan sangat membantu para animator untuk membuat animasi menjadi semakin mudah dan menarik. Adobe Flash CS6 telah mampu membuat dan mengolah teks maupun objek dengan efek tiga dimensi, sehingga hasilnya tampak lebih menarik (Herliana \& Renaldi, 2015).

\section{Storyboard}

Storyboard adalah sketsa gambar yang disusun berurutan sesuai dengan naskah, dengan storyboard kita dapat menyampaikan ide cerita kita kepada orang lain dengan lebih mudah, karena kita dapat menggiring khayalan seseorang mengikuti gambar-gambar yang tersaji, sehingga menghasilkan persepsi yang sama pada ide cerita kita [1]. Storyboard mempunyai peranan sangat penting dalam pengembangan multimedia, digunakan sebagai alat bantu pada tahapan perancangan aplikasi multimedia.

\section{Black Box Testing}

Black box testing merupakan salah satu teknik pengujian aplikasi perangkat lunak, dimana teknik pengujian ini memungkinkan kita untuk membuat beberapa kumpulan kondisi masukan yang sepenuhnya akan melakukan semua kebutuhan fungsional untuk program(Rosa, 2013). Pengujian black box bukan teknik alternatif untuk white box. Sebaliknya, ini merupakan pendekatan pelengkap yang mungkin dilakukan mengungkapkan kelas kesalahan yang berbeda dari yang diungkap oleh metode white box(Simarmata, 2010).

\section{Metode Penelitian}

Metode Pengumpulan Data

Dalam penelitian ini, metode pengumpulan data yang digunakan, adalah metode observasi dan studi kepustakaan, berikut penjabarannya:

Peneliti menggunakan metode observasi dengan mengamati secara langsung objek penelitian untuk mendapatkan analisa kebutuhan dari aplikasi multimedia yang akan dirancang.

Peneliti juga mencari sumber referensi yang dijadikan acuan penelitian dari berbagai studi literatur, baik sumber yang berasal dari buku maupun sumber dari internet.

\section{Model Waterfall}

Dalam perancangan aplikasi multimedia penelitian ini, peneliti menggunakan model pengembangan aplikasi waterfall(Pressman, Roger, 2012). Berikut tahapan yang telah dilakukan:

\section{Analisa Kebutuhan Perangkat Lunak}

Peneliti terlebih dahulu melakukan pengumpulan data dengan melakukan observasi pada objek penelitian. Data-data yang dikumpulkan seperti pengetahuan seputar provinsi-provinsi di Indonesia yang telah dipelajari pada objek penelitian, analisa kebutuhan user atau pihak yang akan jadi target penggunaan aplikasi, serta kebutuhankebutuhan sistem dari aplikasi yang akan dirancang.

Aplikasi multimedia penelitian ini dirancang untuk dijadikan media penunjang pembelajaran bagi siswa dalam mendapatkan pengetahuan seputar provinsi-provinsi yang ada di Indonesia. Berikut beberapa hal mengenai tahapan yang dilakukan dalam analisa spesifikasi kebutuhan perangkat lunak untuk aplikasi yang dirancang, diantaranya yaitu:

Peneliti melakukan analisa seputar ilmu pengetahuan provinsi-provinsi di Indonesia yang diberikan guru kepada siswa SDN Cipondoh 4 Tangerang.

Peneliti melakukan analisa mengenai user yang akan menggunakan aplikasi beserta karakteristik dari user tersebut terhadap penggunaan teknologi multimedia.

Peneliti melakukan analisa terhadap user interface dan spesifikasi kebutuhan aplikasi yang disesuaikan dengan kebutuhan user. 


\section{Desain}

Setelah tahapan analisa kebutuhan perangkat lunak dilakukan, maka tahapan selanjutnya peneliti melakukan perancangan desain dari aplikasi multimedia penelitian ini. Desain rancangan aplikasi multimedia ini menggunakan storyboard sebagai dokumentasi perancangan aplikasi.

\section{Pembuatan Kode Program}

Dalam tahapan pembuatan kode program, peneliti menggunakan editor aplikasi multimedia Adobe Flash untuk merancang dan membuat aplikasi kedalam media komputer berdasarkan desain sebelumnya dalam bentuk dokumentasi, dalam tahapan ini terdapat pula kegiatan, seperti penulisan kode program, memasukan objek gambar, video, latar belakang menu aplikasi serta suara yang dibutuhkan.

\section{Pengujian}

Setelah aplikasi selesai dirancang, kemudian peneliti melakukan pengujian aplikasi dengan menggunakan metode Black Box Testing. Proses pengujian terhadap aplikasi fokus terhadap proses masukan dan keluaran yang terdapat pada aplikasi multimedia yang dirancang.

\section{Pendukung (Support) dan Pemeliharaan (Maintenance)}

Dalam tahapan ini peneliti secara berkala akan melakukan pembaharuan (update) data aplikasi sesuai dengan perkembangan teknologi software dan hardware terkini agar siklus hidup aplikasi berjalan baik.

\section{HASIL DAN PEMBAHASAN}

\section{A. Analisa Kebutuhan Aplikasi}

Berdasarkan penelitian yang telah dilakukan, berikut hasil analisa kebutuhan perancangan aplikasi multimedia flash peta provinsi Indonesia di SDN Cipondoh 4 Tangerang:

1. Aplikasi yang dirancang harus dapat menampilkan provinsi-provinsi yang ada di Indonesia dalam bentuk peta nasional.

2. Aplikasi yang dirancang menampilkan informasi nama provinsi-provinsi yang ada di Indonesia.

3. Aplikasi yang dirancang menampilkan informasi mengenai pengenalan seni dan kebudayaan dari masing-masing provinsi yang ada di Indonesia.

4. Aplikasi yang dirancang mampu menampilkan informasi mengenai tarian tradisional dalam bentuk video.

5. Aplikasi yang dirancang harus dapat digunakan dengan mudah untuk siswa sekolah dasar dengan tampilan dan menu yang user friendly.

6. Aplikasi yang dirancang menyediakan media latihan-latihan soal dari materi yang disediakan, sebagai bahan evaluasi dari penggunaan aplikasi.

\section{B. Storyboard}

Berikut beberapa gambaran dari storyboard yang telah dirancang untuk penelitian perancangan aplikasi ini didalam tahapan desain, yaitu:

\section{Storyboard Menu Aplikasi}

\begin{tabular}{|l|c|c|}
\hline \multicolumn{1}{|c|}{ VISUAL } & SKETSA & AUDIO \\
\hline Dalam frame ini & Judul & Musik: \\
terdapat 2 & Materi & Ada \\
tombol button & Quiz & \\
yaitu materi dan & Help & \\
quiz & About & \\
& Musik & \\
& Exit & \\
& & \\
\hline
\end{tabular}

Sumber : Hasil Penelitian (2019)

Gambar III.1Storyboard Menu Aplikasi

\section{Storyboard Materi}

\begin{tabular}{|l|c|c|}
\hline \multicolumn{1}{|c|}{ VISUAL } & SKETSA & AUDIO \\
\hline $\begin{array}{l}\text { Dalam frame ini } \\
\text { terdapat peta } \\
\text { provinsi } \\
\text { indonesia dan } \\
\text { masing masing } \\
\text { terdapat } \\
\text { penjelasannya }\end{array}$ & Peta Provinsi Indonesia & Musik: \\
Hda \\
\end{tabular}

Sumber : Hasil Penelitian (2019)

Gambar III.2Storyboard Materi

\section{StoryboardQuiz}

\begin{tabular}{|l|c|c|}
\hline \multicolumn{1}{|c|}{ VISUAL } & SKETSA & AUDIO \\
\hline $\begin{array}{l}\text { Dalam frame } \\
\text { ini terdapat } \\
\text { teks }\end{array}$ & Teks & $\begin{array}{c}\text { Musik: } \\
\text { Ada }\end{array}$ \\
$\begin{array}{l}\text { pertanyaan, } \\
\text { dan peta } \\
\text { provinsi }\end{array}$ & $\begin{array}{c}\text { Peta Provinsi } \\
\text { Indonesia }\end{array}$ \\
$\begin{array}{l}\text { sebagai } \\
\text { pilihan } \\
\text { jawabannya }\end{array}$ & Help About Musik Exit & \\
\hline
\end{tabular}


Sumber : Hasil Penelitian (2019)

Gambar III.3StoryboardQuiz

\section{StoryboardHelp}

\begin{tabular}{|c|c|c|}
\hline VISUAL & SKETSA & AUDIO \\
\hline $\begin{array}{c}\text { Dalam frame ini } \\
\text { terdapat } 1 \text { button } \\
\text { keluar dan } \\
\text { penjelasan } \\
\text { mengenai } \\
\text { bantuan } \\
\text { penggunaan } \\
\text { aplikasi }\end{array}$ & Keluar & Musik: \\
\hline
\end{tabular}

\section{Sumber : Hasil Penelitian (2019)}

Gambar III.4Storyboard Help

5. Storyboard Provinsi

\begin{tabular}{|c|c|c|}
\hline VISUAL & SKETSA & AUDIO \\
\hline $\begin{array}{l}\text { Dalam frame } \\
\text { ini terdapat }\end{array}$ & $\begin{array}{ll}\text { Teks } & \text { Keluar } \\
\text { Gambar } & \text { Teks }\end{array}$ & $\begin{array}{l}\text { Musik: } \\
\text { Ada }\end{array}$ \\
\hline $\begin{array}{ll}5 & \text { button, } \\
\text { vaitu pakaian }\end{array}$ & Button Button & \\
\hline $\begin{array}{l}\text { adat, senjata } \\
\text { tradisional, } \\
\text { rumah adat, } \\
\text { tari } \\
\text { tradisional, } \\
\text { dan keluar }\end{array}$ & Button Button & \\
\hline
\end{tabular}

Sumber : Hasil Penelitian (2019)

Gambar III.5StoryboardProvinsi

\section{Rancangan Antar Muka}

Berikut ini rancangan antar muka (user interface) dari storyboard yang telah dibuat.

1. Rancangan Antar Muka Menu Aplikasi

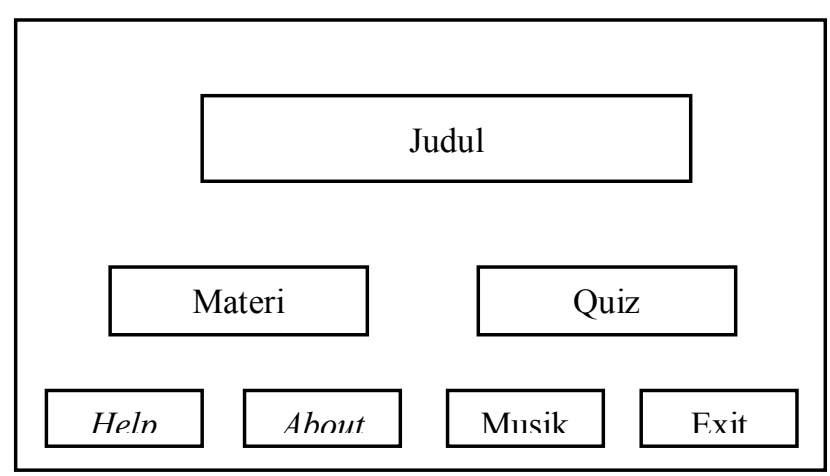

Sumber : Hasil Penelitian (2019)

Gambar III.6Rancangan Antar Muka Menu Aplikasi

\section{Rancangan Antar Muka Materi}

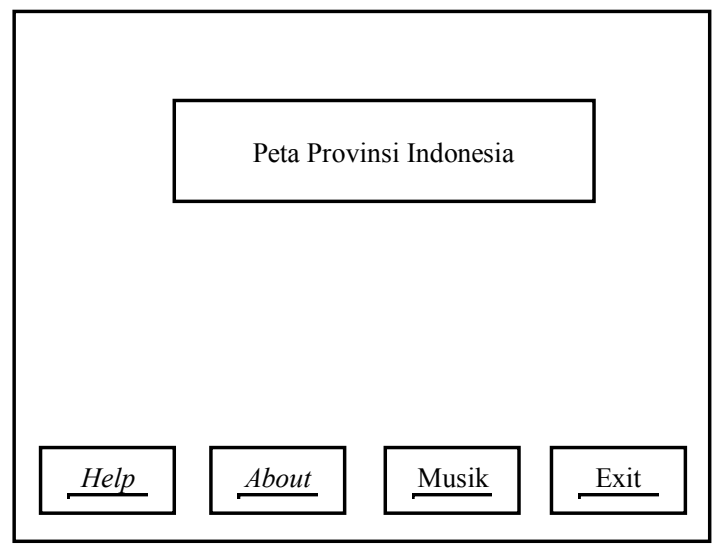

Sumber : Hasil Penelitian (2019)

Gambar III.7Rancangan Antar Muka Materi

\section{Rancangan Antar Muka Quiz}

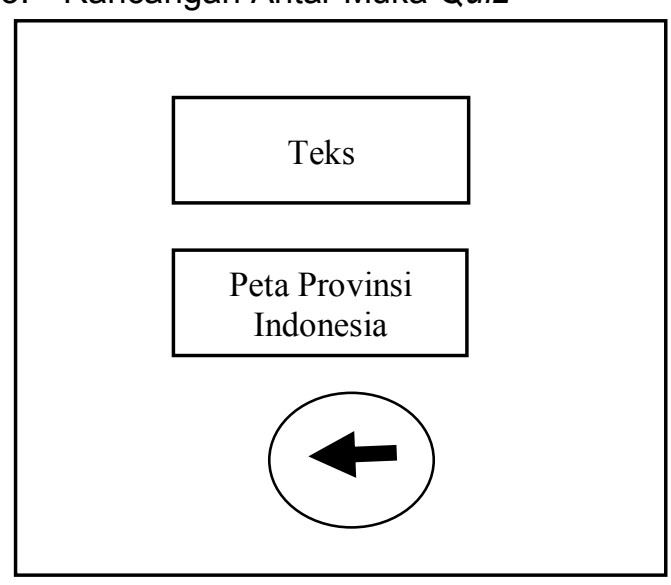

Sumber : Hasil Penelitian (2019) Gambar III.8Rancangan Antar Muka Materi 
4. Rancangan Antar Muka Provinsi

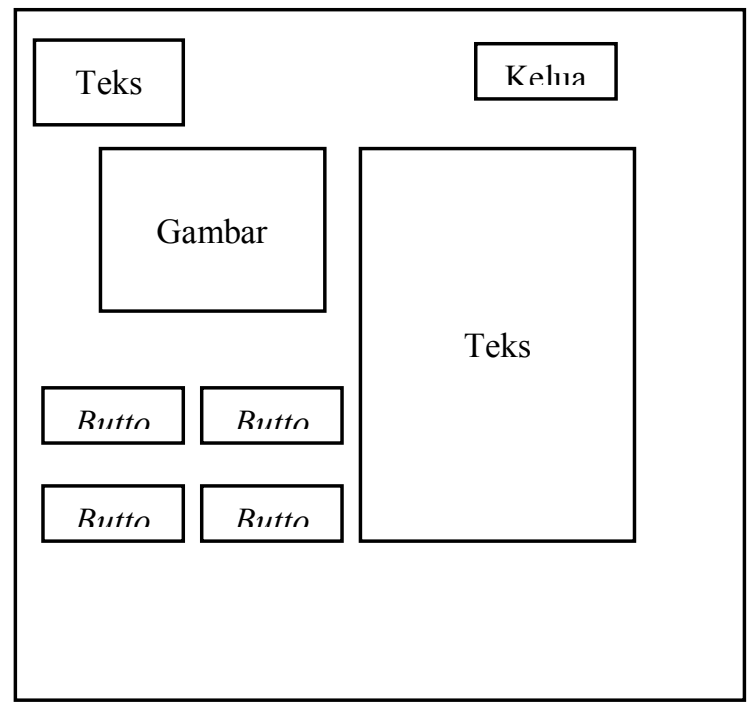

Sumber : Hasil Penelitian (2019)

Gambar III.9Rancangan Antar Muka Provinsi

\section{Tampilan Aplikasi}

Berikut beberapa tampilan aplikasi multimedia flash peta provinsi Indonesia di SDN Cipondoh 4 Tangerang:

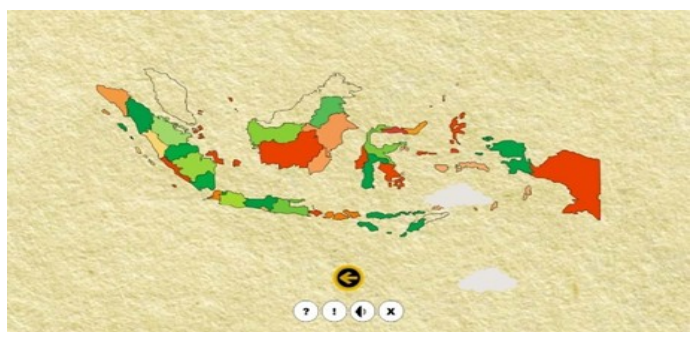

Sumber : Hasil Penelitian (2019)

Gambar III.10 Tampilan Antar Muka Provinsi

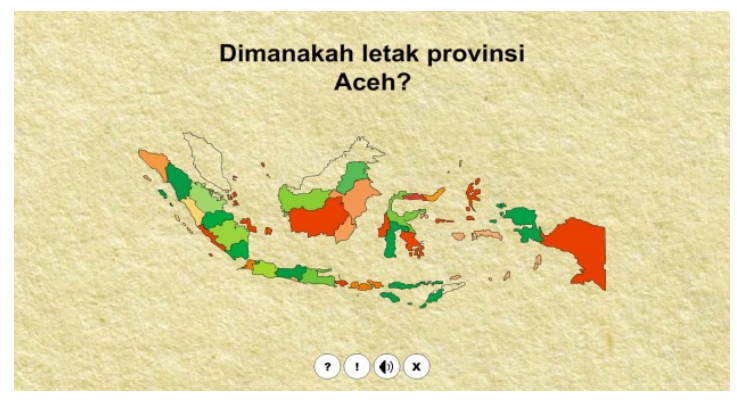

Sumber : Hasil Penelitian (2019)

Gambar III.11 Tampilan Antar Muka Materi Quiz

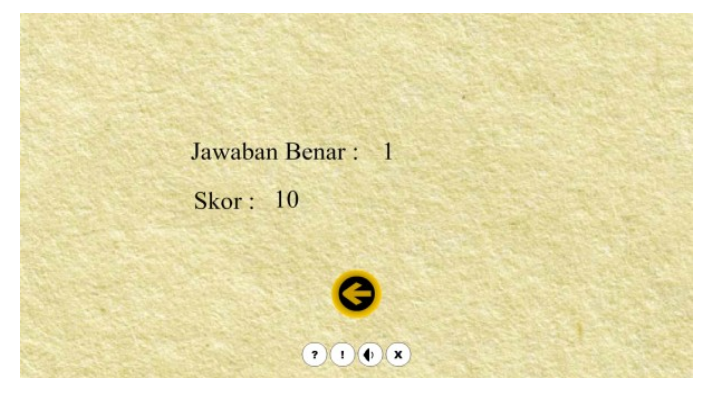

Sumber : Hasil Penelitian (2019)

Gambar III.12Tampilan jawaban Quiz

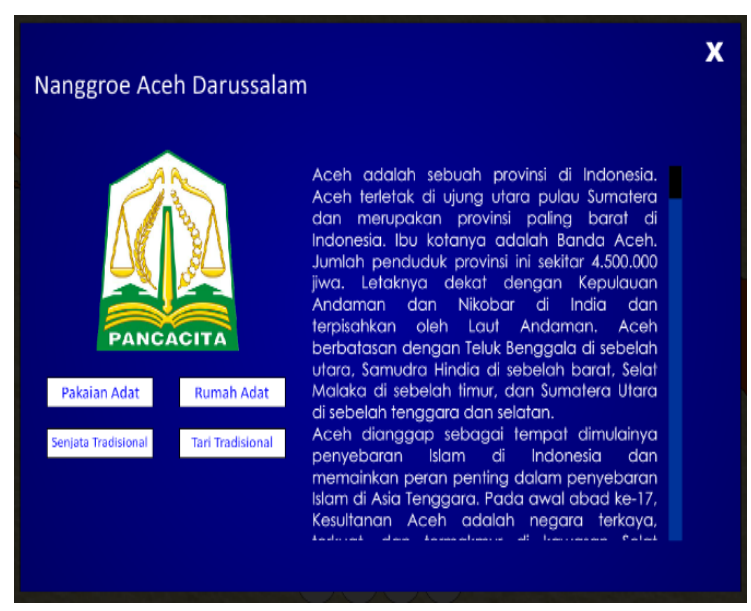

Sumber : Hasil Penelitian (2019)

Gambar III.13 Tampilan Antar Muka Info provinsi

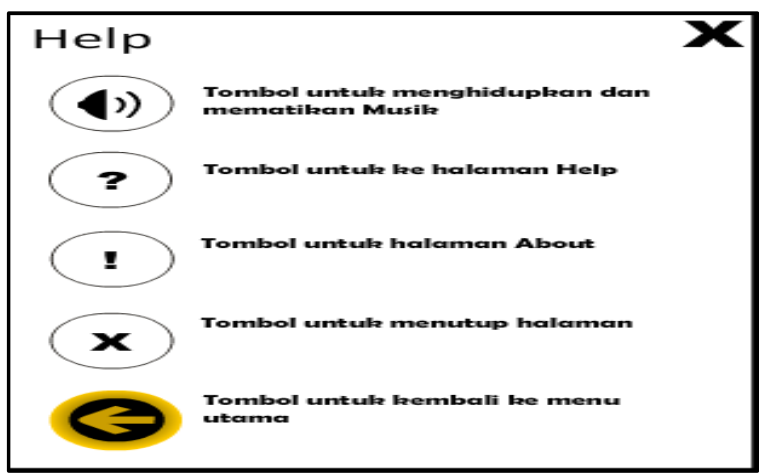

Sumber : Hasil Penelitian (2019)

Gambar III.14 Tampilan Antar muka Help 


\section{E. Black Box Testing}

Berikut hasil dari pengujian black box testing terhadap proses masukan dan keluaran pada aplikasi:

1. Pengujian Halaman Menu

Tabel III.1 Pengujian Halaman Menu

\begin{tabular}{|c|c|c|c|}
\hline $\begin{array}{l}\text { Input/ } \\
\text { Event }\end{array}$ & Proses & $\begin{array}{l}\text { Output/ } \\
\text { Next } \\
\text { Stage }\end{array}$ & $\begin{array}{l}\text { Hasil } \\
\text { Pengujian }\end{array}$ \\
\hline $\begin{array}{l}\text { Tombol } \\
\text { Materi }\end{array}$ & $\begin{array}{l}\text { on (release) \{ } \\
\text { gotoAndPlay(196); } \\
\text { kemana = } \\
\text { 'materi'; } \\
\} \\
\text { Penjelasan: } \\
\text { Ketika mengklik } \\
\text { tombol Materi, } \\
\text { maka akan tampil } \\
\text { menu Peta } \\
\text { Provinsi }\end{array}$ & $\begin{array}{l}\text { Tampilan } \\
\text { peta } \\
\text { akan } \\
\text { keluar } \\
\text { setelah } \\
\text { mengklik } \\
\text { tombol } \\
\text { materi }\end{array}$ & $\begin{array}{l}\text { Hasil } \\
\text { Sesuai }\end{array}$ \\
\hline $\begin{array}{l}\text { Tombol } \\
\text { Quiz }\end{array}$ & $\begin{array}{l}\text { on (release) \{ } \\
\text { gotoAndPlay(196); } \\
\quad \text { kemana = } \\
\text { 'quiz'; } \\
\} \\
\text { Penjelasan: } \\
\text { Ketika mengklik } \\
\text { tombol Quiz, } \\
\text { maka akan tampil } \\
\text { halaman awal } \\
\text { Quiz }\end{array}$ & $\begin{array}{l}\text { Tampilan } \\
\text { awal } \\
\text { Quiz } \\
\text { akan } \\
\text { muncul } \\
\text { setelah } \\
\text { mengklik } \\
\text { tombol }\end{array}$ & $\begin{array}{l}\text { Hasil } \\
\text { Sesuai }\end{array}$ \\
\hline
\end{tabular}

Sumber :hasilpenelitian (2019)

2. Pengujian Halaman Materi

Tabel III.2. Pengujian Halaman Materi

\begin{tabular}{|c|c|c|c|}
\hline $\begin{array}{l}\text { Input/ } \\
\text { Event }\end{array}$ & Proses & $\begin{array}{l}\text { Output/ } \\
\text { Next } \\
\text { Stage }\end{array}$ & $\begin{array}{l}\text { Hasil } \\
\text { Pengujia } \\
\mathrm{n}\end{array}$ \\
\hline $\begin{array}{l}\text { Tombol } \\
\text { Help } \\
\text { (?) }\end{array}$ & $\begin{array}{l}\text { on (release) \{ } \\
\text { bawah.gotoAndPlay } \\
(2) ; \\
\} \\
\text { Penjelasan: } \\
\text { Ketika di klik, maka } \\
\text { akan muncul } \\
\text { tampilan bantuan } \\
\text { dalam } \\
\text { menggunakan } \\
\text { animasi tersebut }\end{array}$ & $\begin{array}{l}\text { Tampila } \\
\mathrm{n} \text { Help } \\
\text { akan } \\
\text { muncul }\end{array}$ & $\begin{array}{c}\text { Hasil } \\
\text { Sesuai }\end{array}$ \\
\hline $\begin{array}{l}\text { Tombol } \\
\text { About } \\
(!)\end{array}$ & $\begin{array}{l}\text { on (release) \{ } \\
\text { bawah.gotoAndPlay } \\
(3) ; \\
\} \\
\text { Penjelasan: } \\
\text { Ketika mengklik } \\
\text { tombol About, maka } \\
\text { akan muncul }\end{array}$ & $\begin{array}{l}\text { Tampila } \\
\mathrm{n} \\
\text { tentang } \\
\text { aplikasi }\end{array}$ & $\begin{array}{c}\text { Hasil } \\
\text { Sesuai }\end{array}$ \\
\hline
\end{tabular}

\begin{tabular}{|c|c|c|c|}
\hline & entang aplikas & & \\
\hline $\begin{array}{l}\text { Tombol } \\
\text { Musik } \\
\text { (ikon } \\
\text { speake } \\
\text { r) }\end{array}$ & $\begin{array}{l}\text { Ketika mengklik } \\
\text { tombol musik, maka } \\
\text { musik akan berhenti } \\
\text { ataupun diputar } \\
\text { kembali }\end{array}$ & $\begin{array}{l}\text { Musik } \\
\text { akan } \\
\text { menyal } \\
\text { a } \\
\text { ataupu } \\
\mathrm{n} \\
\text { berhent } \\
\text { i diputar }\end{array}$ & $\begin{array}{l}\text { Hasil } \\
\text { Sesuai }\end{array}$ \\
\hline $\begin{array}{l}\text { Tombol } \\
\text { Keluar } \\
(\mathrm{X})\end{array}$ & $\begin{array}{l}\text { on (release) \{ } \\
\text { fscommand("quit"); } \\
\} \\
\text { Penjelasan: } \\
\text { Ketika mengklik } \\
\text { icon "X", maka akan } \\
\text { keluar dari halaman } \\
\text { Materi }\end{array}$ & $\begin{array}{l}\text { Akan } \\
\text { muncul } \\
\text { pesan } \\
\text { "Yakin } \\
\text { mau } \\
\text { Keluar? } \\
\text { " }\end{array}$ & $\begin{array}{c}\text { Hasil } \\
\text { Sesuai }\end{array}$ \\
\hline
\end{tabular}

Sumber :hasilpenelitian (2019)

\section{Pengujian Halaman Awal Quiz}

Tabel III.3. Pengujian Halaman Awal Quiz

\begin{tabular}{|c|c|c|c|}
\hline $\begin{array}{l}\text { Input/ } \\
\text { Event }\end{array}$ & Proses & $\begin{array}{l}\text { Output/ } \\
\text { Next } \\
\text { Stage }\end{array}$ & $\begin{array}{l}\text { Hasil } \\
\text { Pengujia } \\
n\end{array}$ \\
\hline $\begin{array}{l}\text { Tombo } \\
\text { I Start }\end{array}$ & $\begin{array}{l}\text { on (release) }\{ \\
\text { gotoAndStop(2); } \\
\text { \} } \\
\text { Penjelasan: } \\
\text { Ketika mengklik } \\
\text { tomblo start, maka } \\
\text { akan muncul } \\
\text { halaman Quiz }\end{array}$ & $\begin{array}{l}\text { Tampila } \\
\mathrm{n} \\
\text { Halama } \\
\mathrm{n} \quad \text { Quiz } \\
\text { muncul }\end{array}$ & $\begin{array}{l}\text { Hasil } \\
\text { Sesuai }\end{array}$ \\
\hline $\begin{array}{l}\text { Tombo } \\
\text { Home }\end{array}$ & $\begin{array}{l}\text { on (release) }\{ \\
\text { loadMovieNum('Pet } \\
\text { a Indonesia.swf', } \\
1 \text { ); } \\
\} \\
\text { Penjelasan: } \\
\text { Ketika mengklik } \\
\text { icon " } \square \text { ", maka } \\
\text { akan langsung } \\
\text { kembali me } \\
\text { halaman menu }\end{array}$ & $\begin{array}{l}\text { Akan } \\
\text { kembali } \\
\text { ke } \\
\text { halaman } \\
\text { Menu }\end{array}$ & $\begin{array}{l}\text { Hasil } \\
\text { Sesuai }\end{array}$ \\
\hline
\end{tabular}

\section{Pengujian Halaman Help}

Tabel III.4 Pengujian Halaman Help

\begin{tabular}{|l|l|l|l|}
\hline $\begin{array}{l}\text { Input/ } \\
\text { Event }\end{array}$ & Proses & $\begin{array}{l}\text { Output/ } \\
\text { Next } \\
\text { Stage }\end{array}$ & $\begin{array}{l}\text { Hasil } \\
\text { Penguji } \\
\text { an }\end{array}$ \\
\hline $\begin{array}{l}\text { Tomb } \\
\text { ol }\end{array}$ & on (release) \{ & $\begin{array}{l}\text { Tampil } \\
\text { Help }\end{array}$ & Hasil \\
Help & bawah.gotoAndPlay & $\begin{array}{l}\text { Sanai } \\
\text { muncul }\end{array}$ & \\
& $(2) ;$ & & \\
& \} & & \\
& Penjelasan: & & \\
\hline
\end{tabular}




\begin{tabular}{|l|l|l|l|}
\hline & $\begin{array}{l}\text { Ketika di klik, maka } \\
\text { akan muncul } \\
\text { tampilan bantuan } \\
\text { dalam } \\
\text { menggunakan } \\
\text { animasi tersebut }\end{array}$ & & \\
\hline $\begin{array}{l}\text { Tomb } \\
\text { ol } \\
\text { Kelua } \\
\mathrm{r}\end{array}$ & $\begin{array}{l}\text { on (release) }\{\text { gotoAndPlay(1); } \\
\text { Ketika mengklik } \\
\text { icon "X", maka akan } \\
\text { langsung keluar } \\
\text { dari halaman Help }\end{array}$ & $\begin{array}{l}\text { Taman } \\
\text { menghila }\end{array}$ & $\begin{array}{c}\text { Hasil } \\
\text { Sesuai }\end{array}$ \\
\hline
\end{tabular}

Sumber :hasilpenelitian (2019)

\section{Pengujian Halaman Peta Provinsi}

Tabel III.4 Pengujian Halaman Peta Provinsi

\begin{tabular}{|c|c|c|c|}
\hline $\begin{array}{l}\text { Input/ } \\
\text { Event }\end{array}$ & Proses & $\begin{array}{l}\text { Output/ } \\
\text { Next Stage }\end{array}$ & $\begin{array}{l}\text { Hasil } \\
\text { Pengujian }\end{array}$ \\
\hline $\begin{array}{l}\text { Tombol } \\
\text { Pada } \\
\text { Peta } \\
\text { Provins } \\
\text { i yang } \\
\text { dipilih }\end{array}$ & 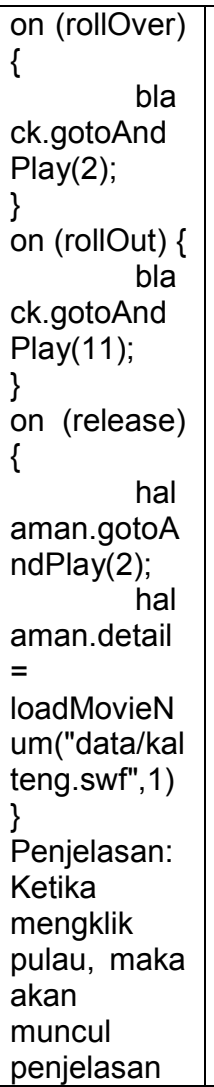 & $\begin{array}{l}\text { Akan } \\
\text { tampilPenjelas } \\
\text { anmengenaipr } \\
\text { ovinsi yang } \\
\text { dipilih }\end{array}$ & $\begin{array}{l}\text { Hasil } \\
\text { Sesuai }\end{array}$ \\
\hline $\begin{array}{l}\text { Tombol } \\
\text { Pakaia } \\
\text { n Adat }\end{array}$ & $\begin{array}{l}\text { on (release) }\{ \\
\text { _parent.hala } \\
\text { man.gotoAnd } \\
\text { Play(2); } \\
\text { _parent.hala } \\
\text { man.mediaa= } \\
\text { 'pakaian'; } \\
\text { \} } \\
\text { Penjelasan: } \\
\text { Ketika } \\
\text { mengklik } \\
\text { tombol } \\
\text { pakaian adat, } \\
\text { maka akan }\end{array}$ & $\begin{array}{l}\text { Akan } \\
\text { tampilgambar } \\
\text { pakaianadatp } \\
\text { rovinsi yang } \\
\text { dipilih }\end{array}$ & $\begin{array}{l}\text { Hasil } \\
\text { Sesuai }\end{array}$ \\
\hline
\end{tabular}

\begin{tabular}{|c|c|c|c|}
\hline & $\begin{array}{l}\text { muncul } \\
\text { gambar } \\
\text { pakaian adat }\end{array}$ & & \\
\hline $\begin{array}{l}\text { Tombol } \\
\text { Senjat } \\
\text { a } \\
\text { Tradisi } \\
\text { onal }\end{array}$ & $\begin{array}{l}\text { on (release) \{ } \\
\text { parent.hala } \\
\text { man.gotoAnd } \\
\text { Play(2); } \\
\text { pparent.hala } \\
\text { man.mediaa= } \\
\text { 'senjata'; } \\
\text { \} } \\
\text { Penjelasan: } \\
\text { Ketika } \\
\text { mengklik } \\
\text { tombol } \\
\text { senjata } \\
\text { tradisional, } \\
\text { maka akan } \\
\text { muncul } \\
\text { penjelasan }\end{array}$ & $\begin{array}{l}\text { Akan } \\
\text { tampilgambar } \\
\text { danpenjelasa } \\
\text { ndariprovinsi } \\
\text { yang dipilih }\end{array}$ & $\begin{array}{c}\text { Hasil } \\
\text { Sesuai }\end{array}$ \\
\hline $\begin{array}{l}\text { Tombol } \\
\text { Rumah } \\
\text { adat }\end{array}$ & $\begin{array}{l}\text { on (release) \{ } \\
\text { parent.hala } \\
\text { man.gotoAnd } \\
\text { Play(2); } \\
\text { parent.hala } \\
\text { man.mediaa= } \\
\text { 'rumah'; } \\
\text { \} } \\
\text { Penjelasan: } \\
\text { Ketika } \\
\text { mengklik } \\
\text { tombol rumah } \\
\text { adat, maka } \\
\text { akan muncul } \\
\text { penjelasan }\end{array}$ & $\begin{array}{l}\text { Akan } \\
\text { tampilgambar } \\
\text { danpenjelasa } \\
\text { ndariprovinsi } \\
\text { yang dipilih }\end{array}$ & $\begin{array}{l}\text { Hasil } \\
\text { Sesuai }\end{array}$ \\
\hline $\begin{array}{l}\text { Tombol } \\
\text { Tari } \\
\text { Tradisi } \\
\text { onal }\end{array}$ & $\begin{array}{l}\text { on (release) \{ } \\
\text { parent.hala } \\
\text { man.gotoAnd } \\
\text { Play(2); } \\
\text { pparent.hala } \\
\text { man.mediaa= } \\
\text { 'tarian'; } \\
\text { \} } \\
\text { Penjelasan: } \\
\text { Ketika } \\
\text { mengklik } \\
\text { tombol } \\
\text { tersebut, } \\
\text { maka akan } \\
\text { muncul video }\end{array}$ & $\begin{array}{l}\text { Akan tampil } \\
\text { video } \\
\text { tentangprovin } \\
\text { si yang dipilih }\end{array}$ & $\begin{array}{l}\text { Hasil } \\
\text { Sesuai }\end{array}$ \\
\hline $\begin{array}{l}\text { Tombol } \\
\text { keluar }\end{array}$ & $\begin{array}{l}\text { on (release) \{ } \\
\text { gotoAndPlay( } \\
\text { "keluar"); } \\
\text { \} } \\
\text { Penjelasan: } \\
\text { Ketika } \\
\text { mengklik icon } \\
\text { "X", maka } \\
\text { akan } \\
\text { langsung } \\
\text { keluar dari } \\
\text { halaman } \\
\text { penjelasan }\end{array}$ & $\begin{array}{l}\text { TampilanPenj } \\
\text { elasanprovins } \\
\text { iakanmenghil } \\
\text { ang }\end{array}$ & $\begin{array}{l}\text { Hasil } \\
\text { Sesuai }\end{array}$ \\
\hline
\end{tabular}

Sumber :hasilpenelitian (2019) 


\section{F. Pendukung Aplikasi (Support)}

Berikut adalah pendukung aplikasi yang diperlukan, terbagi kedalam perangkat keras dan perangkat lunak. Penjabarannya sebagai berikut:

Perangkat keras adalah semua bagian fisik komputer, dibedakan dengan data yang berada di dalamnya atau yang beroperasi didalamnya, dan dibedakan juga dengan perangkat lunak yang menyediakan instruksi untuk perangkat keras dalam menyelesaikan tugasnya aplikasi:

Berikut spesifikasi perangkat keras

1. CPU (Central Processing Unit) Processor Intel Core i3

2. RAM 2,00 GB

3. Hard Disk 320 GB

4. Mouse PS/2

5. Keyboard

6. Monitor dengan resolusi layar 14"

Sedangkan perangkat lunak adalah instruksi langsung komputer untuk melakukan pekerjaan dan dapat ditemukan disetiap aspek kehidupan modern dari aplikasi yang kritis untuk hidup, seperti perangkat pemantau medis dan pembangkit tenaga listrik sampai perangkat hiburan, seperti video game [9]. Berikut spesifikasi perangkat lunak aplikasi:

1. Sistem Operasi yang umum digunakan seperti : Microsoft Windows,

2. Aplikasi yang digunakan seperti :Adobe Flash CS3 Professional.

\section{KESIMPULAN}

Berdasarkanpenelitianyang telahdilakukan mulai dari tahapan analisa kebutuhan hingga tahapan pengujian dan implementasi aplikasi, maka dapat ditarikkesimpulanbahwaAplikasi berbentuk multimedia flash merupakan media menarik dalam pembelajaran bagi siswa sekolah dasar, dalam penyampaian dan menambah wawasan ilmu pengetahuan seputar provinsi-provinsi yang ada dilndonesia, baik letak geografis maupun seni dan kebudayannya.Siswa-siswi tingkat sekolah dasar dapat dengan mudah dan cepat dalam menggunakan aplikasi, bila rancangan antar muka (user interface) didesain sesuai kebutuhan dari user atau pengguna, Guru mendapatkan media penunjang penyampaian materi provinsi-provinsi Indonesia dari aplikasi multimedia flash ini, selain penyampaian yang biasa dilakukan dikelas secara lisan.Pengembangan aplikasi masih bisa dilakukan dipenelitian lebih lanjut dengan penambahan fitur-fitur informasi seputar provinsi-provinsi di Indonesia.

\section{DAFTAR PUSTAKA}

Adiwisastra, M. (2015). Perancangan Game Kuis Interaktif Sebagai Multimedia Pembelajaran Drill and Practise Untuk Meningkatkan Hasil Belajar Siswa. Informatika, 2, 205-211.

Binanto, I. (2010). Multimedia Digital - Dasar Teori dan Pengembangannya Title. Yogyakarta: Andi.

Hardiyan, \& F. (2017). Animasi Interaktif Berbasis Multimedia Dalam Mempelajari Lagu-Lagu Nasional. Jurnal Swabumi, 5, 142-145.

Hendrayudi. (2009). Pengertian Aplikasi. Yogyakarta: Andi.

Herliana, A., \& Renaldi, A. (2015). Animasi Interaktif Pembelajaran Tari Merak. Jurnal Informatika, 2.

Kurniawan, I. (2015). Membuat Metode Pembelajaran dengan Adobe Flash CS6. Yogyakarta: Andi.

Lesmono, ibnu dwi. (2019). Animasi Berbasis Multimedia Untuk Siswa Berupa Pengenalan Moda Transportasi Dengan Metode Waterfall. Jurnal Swabumi, 7, 2030.

Nazir, M. (2011). Metode Penelitian. Bogor. Bogor: Ghalia Indonesia.

Pranowo, G. (2010). Mastering CoreIDRAW X4. Yogyakarta: Andi.

Pressman, Roger, S. (2012). Rekayasa Perangkat Lunak. Yogyakarta: Andi.

Rosa, M. S. (2013). Rekayasa Perangkat Lunak. Bandung: Informatika.

Saeba. (2008). Modeling dan Animasi Dengan 3D Studio Max 2008 dan 2009. Jakarta: PT. Elexmedia Komputindo.

Simarmata, J. (2010). Rekayasa Perangkat Lunak. Yogyakarta: Andi.

Suheri, A. (2006). Animasi Multimedia Pembelajaran. Media Teknologi Universitas Surya Kencana Cianjur, 2.

Virvou, M. (2005). Combining Software Games with Education: Evaluation of Its Educational Effectivinnes. Journal Educational Technology and Society, 8, 54-65. 
